\title{
Alvin W. Gouldner and Industrial Sociology at Columbia University
}

James Chriss

Cleveland State University, j.chriss@csuohio.edu

Follow this and additional works at: https://engagedscholarship.csuohio.edu/clsoc_crim_facpub

Part of the Criminology Commons, and the Work, Economy and Organizations Commons

How does access to this work benefit you? Let us know!

\section{Publisher's Statement}

The definitive version is available at www3.interscience.wiley.com

\section{Repository Citation}

Chriss, James, "Alvin W. Gouldner and Industrial Sociology at Columbia University" (2001). Sociology \& Criminology Faculty Publications. 24.

https://engagedscholarship.csuohio.edu/clsoc_crim_facpub/24

This Article is brought to you for free and open access by the Sociology \& Criminology Department at EngagedScholarship@CSU. It has been accepted for inclusion in Sociology \& Criminology Faculty Publications by an authorized administrator of EngagedScholarship@CSU. For more information, please contact library.es@csuohio.edu. 


\title{
ALVIN W. GOULDNER AND INDUSTRIAL SOCIOLOGY AT COLUMBIA UNIVERSITY
}

\author{
James J. Chriss, Cleveland State University
}

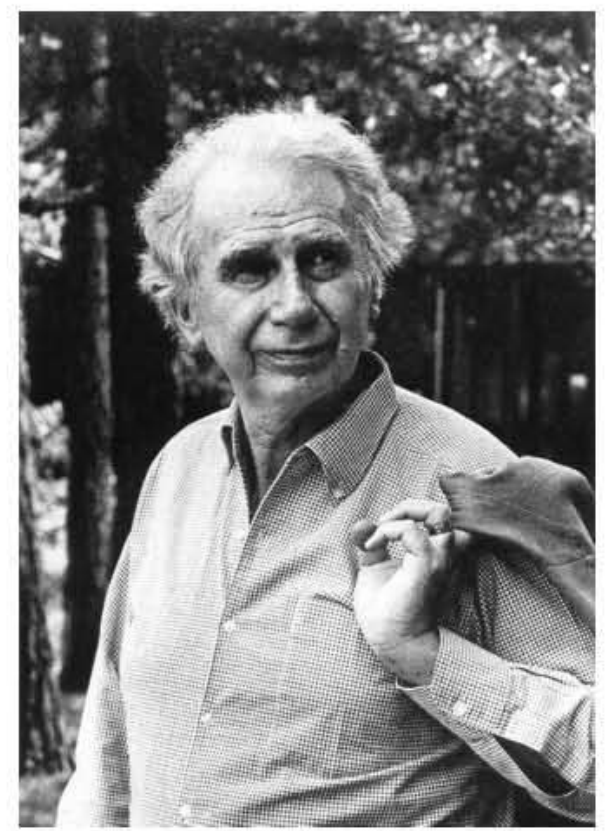

\begin{abstract}
Alvin W. Gouldner (1920-1980) was a prolific sociologist of the post-World War I era who spent the early part of his career (the 1950s) in the field of industrial sociology. A case study of Gouldner's early life and career is useful insofar as it intertwines with the development of industrial sociology as a distinct subfield within sociology. Through this analysis we are also better able to understand how and in what ways a burgeoning organizational studies program devel oped at Columbia University during the $1940 \mathrm{~s}$. This anal$y$ sis of the historical and cultural contexts within which Gouldner came to prominence as an industrial sociologist at Columbia, and the intellectual program that resulted, can also help shed light on more recent trends in organizational studies. (c) 2001 John Wiley \& Sons, Inc.
\end{abstract}

There are a variety of good reasons for studying the life and tim es of Alvin W. Gouldner. First, Gouldner was one of the more prolific and influential sociologists of the post-WWI era. Although in this article I will be concentrating exclusively on his early career as a standout 
in the field of industrial sociology, Gouldner contributed novel insights into and reassessments of a number of additional substantive areas, including functionalist theory (Gouldner, 1956, 1959a, 1959b, 1960, 1970a, 1970b, 1973a, 1973b; Gouldner \& Peterson, 1962), critical theory and Marxism (Gouldner, 1974b, 1974c, 1977-1978, 1980, 1982, 1985), the role of intellectuals in modern society (Gouldner, 1957, 1958, 1975-1976, 1978a, 1978b, 1979, 1983, 1985), the communications revolution (Gouldner, 1976a, 1978c), the sociology of knowledge (Gouldner, 1965), and the interplay between science and ideology (Gouldner, 1962, 1968, $1969,1974 a, 1975,1976 b)$. Second, an examination of Gouldner's early life and career affords a case study in the rise of industrial sociology as a special subfield within sociology beginning in the $1920 \mathrm{~s}$, as well as the creation and growth of the Columbia University department of sociology, concentrating especially on the 1930s through the 1950s. Third, Gouldner was a truly interesting character whose belligerent and impetuous interpersonal style made news virtually everywhere he went (see, e.g., Alt, 1981; Colvard, 1990; Coser, 1982; Etzkowitz, 1991; Hamblin, 1989; Nord, 1992; Stark, 1991). That is to say, beyond the importance of Gouldner's ideas, the story of Gouldner's life as a man, as a sociologist, as an intellectual, and as an outlaw Marxist, is also interesting and worth telling. ${ }^{1}$

\section{THE RISE OF INDUSTRIAL SOCIOLOGY}

As Miller and Form (1951) have suggested, the beginnings of industrial sociology as a specialized field within sociology can be traced to the Hawthorne experiments that took place at the Western Electric Company in Chicago between 1924 and 1927. Industrialization, which already had taken firm hold across Western society by the early $1900 \mathrm{~s}$, had given rise to a unique social form known as the bureaucracy or formal organization. Max Weber put organizational study "on the map," as it were, and by the time of his death in 1920 his work had laid the groundwork for the development of a full-blown research and theory agenda in bureaucracy and formal organization (see Fischer \& Sirianni, 1984; Parsons, 1937; ZeyFerrell \& Aiken, 1981).

Although Weber's analysis of bureaucracy grew out of his concern with the pathological conditions of modernity associated with secularization, rationalization, and the overweening emphasis being placed on efficiency and the values of the marketplace, many early studies in the field of industrial or organizational sociology did not necessarily adopt Weber's latent critical perspective. Indeed, the Western Electric studies mentioned above were overtly dedicated to unearthing the relationship between work efficiency and characteristics of the bureaucracy.

In a nutshell, these now infamous studies led to the discovery of the "Hawthorne effect," namely, the fact that people will alter their behavior if they know they are being observed. The Western Electric studies were concerned with understanding the conditions under which worker productivity and efficiency would increase. Physical conditions at work, such as lighting, and other factors, such as hours worked or employee wages and benefits, were adjusted to see how such variations would impact measures of employee productivity. Surprisingly, almost all the experimental conditions imposed on the workers produced the same effect: productivity increased.

Because so much overt attention was being trained on them, workers in the organization

1. Here I am unable to expand upon this third point. For a fuller discussion of Gouldner's temperament and how it impacted his scholarly work and personal life, see Chriss (1999a, 2000). 
felt a greater sense of importance and obligation than usual, and wanted to put on a "good show" for the researchers. The discovery that worker attitudes have a profound impact on worker productivity and efficiency led to a new emphasis being placed on the social organization of the bureaucracy and especially the nature of manager-employee relations. By the 1930s Elton Mayo (1933) had put the lessons of the Hawthorne studies into practice with his program of human relations management. In essence, industrial sociology was built on the discoveries, running from Weber through the Hawthorne experiments of the 1920 s and into new management practices and theory of the 1930s, of the broader social forces that had been unleashed with the rise of industrial civilization.

Sociology was well positioned, then, to contribute substantially to the understanding and efficient operation of the bureaucracy once it was determined that the nature of group life and human relations were intimately connected to employee motivation, productivity, and work satisfaction. Between the mid-1930s and early 1950s interest within sociology on issues of work, industry, and bureaucracy grew enormously. For example, in 1946 the American Sociological Society created a special Section on Industrial Sociology (Miller \& Form, 1951, p. 10).

By the time Alvin Gouldner had arrived at Columbia in 1943, then, industrial sociology was already becoming well established as a legitimate field of specialty within sociology. In the next few sections, the social context of Gouldner's work in industrial sociology at Columbia will be illuminated via a brief description of the circumstances that led him there. Following that, a history of Columbia's sociology department will be provided.

\section{GOULDNER AND COLUMBIA SOCIOLOGY}

Before arriving at Columbia University to begin work on his master's degree, Gouldner attended City College of New York (CCNY) beginning in 1937. A son of Jewish immigrants newly arrived to the United States at the turn of the century, Gouldner grew up in Harlem, a part of New York City that in the 1920s and 1930s was marked by great ethnic and racial diversity, including a large Jewish population (Gurock, 1979; Horowitz, 1990). CCNY was America's first urban college and had free tuition and open admission to anyone who qualified. By the time Gouldner was of college age the college was increasingly servicing the needs of the local and growing Jewish population. City College was in fact an incubator for an impressive cadre of New York Jewish intellectuals who came of age just before World War II (Gorelick, 1981; Page, 1982; Traub, 1994). In the social sciences and humanities alone, CCNY produced such notables as Irving Howe, Irving Kristol, Daniel Bell, Seymour Martin Lipset, Morroe Berger, Julius Rosenberg, Nathan Glazer, Peter Rossi, Philip Selznick, Alfred Kazin, and of course Gouldner - many of whom went on to attend Columbia University (Page, 1982; Waters, 1996, p. 22).

Gouldner graduated from CCNY in 1941 with a BBA degree. Aside from the fact that there was a close affinity between CCNY and Columbia University during this time (for reasons we have discussed and for others that will become apparent shortly), the prestige of Columbia's sociology department had been rising ever since the arrival of William Ogburn in 1928 (Turner \& Turner, 1990, p. 49). Ogburn's strong emphasis on statistical technique offered a viable alternative to the University of Chicago's emphasis on problems-oriented research aimed at ameliorating any number of urban social ills (Halas, 2001). Gouldner's more quantitative, business background seemed a natural fit with Columbia's emphasis on "scientific" sociology. 
But this of course is not the entire story. Before we can understand more fully the nature and circumstance of Gouldner's work in industrial sociology at Columbia, we must examine in closer detail the history of Columbia's sociology department.

\section{The Columbia University Department of Sociology}

The beginnings of the sociology department at Columbia University can be traced back to 1892 . In that year, at the urgings of both the faculty of political science and President Seth Low, Franklin $\mathrm{H}$. Giddings was appointed as lecturer in sociology. To assure the continuing viability of the fledgling sociology department, in 1895 Low went so far as to contribute the cost of what is now the Low Memorial Library on the condition that the Trustees would assume the responsibility for paying the salary of the chair of sociology on a permanent basis (Lipset, 1955, p. 285)

Giddings, who would remain the leading sociologist in the department for the next 30 years, took the sociology department in the same direction as other leading centers of learning. During the first few decades of the $1900 \mathrm{~s}$, intellectual energies were being focused overwhelmingly on the undesirable effects of industrialization and urbanization. Ageneral concern with the social problems of the day - these seemingly inexorably bound up with the twin trends of modernity mentioned above - was evident beyond the confines of the university as well, appearing most prominently among the citizenry in the form of progressive and socialist movements.

Although it is clear that up through the 1920s Columbia sociology's reformist and ameliorative impulses were strong and abiding, Giddings did not want sociology to become identified solely or primarily by the activities of moral philanthropy, settlement houses, social workers and reformers, and other forms of social amelioration. Hence, another strong and somewhat countervailing orientation in sociology began to develop during the 1920 s, namely, the attempt to develop sociology as a "legitimate," positivistic science (Abbott, 1999). Positivistic sociology's major concern would be the collection of data and "facts" about the empirical social world rather than making value judgments about the world and attempting to shape it accordingly (Lipset, 1955, p. 290). Ogburn's arrival in 1928 clearly signaled the department's intent of establishing itself as a center for scientific sociology.

Giddings retired in 1928, and Robert Morrison MacIver ${ }^{2}$ was brought in to the sociology department as executive director (Lipset, 1955, p. 292). Although MacIver had a strong personal concern with the pressing social issues of the day, he shared with Giddings the sentiment that sociology ought to aspire to create systematic theory and to apply these explanations and insights to the central analytical category of social organization. However, what MacIver did not share with Giddings and Ogburn was their unbridled optimism about positivistic methods' overweening emphasis on measurement and quantification. MacIver believed, in fact, that the positivistic strand of sociology had become overly concerned with technique, which consequently hampered the development of systematic sociological theory in the United States (Lipset, 1955, p. 293).

Robert S. Lynd and Edmund de S. Brunner were appointed as full professors in the sociology department in 1931. Lynd, having just published Middletown: A Study in American Culture (1929) with Helen M. Lynd, had already developed a reputation as a leading social researcher. The Lynds' study, a description of stratification and class structure in a midwestern

2. For an informative recent analysis of the broader role MacIver played in American sociology at Columbia University through 1950 , see Halas (2001). 
city, has been described by Lipset (1955, p. 294) as "the most important single research project of the 1920s."

In effect, Lynd and Brunner, as empirical researchers, were brought in to offset somewhat the primarily theoretical orientations of MacIver and Theodore Abel, the latter of whom had been appointed as lecturer to the department in 1929. Lynd's joining the sociology department had a profound impact on both MacIver and the sociology department more generally, but for now it is enough to note that Lynd shared MacIver's distaste for positivistic sociology's obsession with method (Page, 1982, p. 42). Although Lynd was indeed a social researcher, as opposed to the systematic theorist MacIver, Lynd was also an ethnographer who employed largely qualitative methods in most of his important works. Hence, Lynd and MacIver shared a distaste for quantitative methods, or what became known pejoratively as abstractedempiricism (Mills, 1959).

\section{MacIver and Industrial Sociology at Columbia}

We now need to understand how, and to what extent, an orientation toward industrial sociology took hold in Columbia's sociology department beginning in the 1920s. Robert MacIver is primarily responsible for developing a research and theory agenda in this area at Columbia. As Miller and Form (1964, p. 660) note, "The roots of industrial sociology may be traced in the United States to the early interest of sociologists in social problems, including the "labor problem." "One of the early paradigmatic studies that applied systematic theories of social organization to the labor problem was MacIver's (1919) Labor in the Changing World. MacIver's development of the concept of association and his stress on the importance of understanding the relationship between forms of the social group and concrete instances of human behavior within the community, predated most of the later, better-known works in organizational and industrial sociology and psychology, including those of Mayo, Merton, Parsons, Homans, and Chester Barnard (1938), to name a few.

Although MacIver contributed importantly to developing an agenda for organizational studies at Columbia, he chose to use the term "association" rather than "group" or "organization," and thus tended not to be identified with those prominent theorists and researchers in the field of industrial sociology employing a more standard analytical arsenal (see Gordon, 1954; Lazarsfeld \& Merton, 1954; Lipset, 1954; Znaniecki, 1954). Nevertheless, MacIver's strong presence in Columbia's sociology department through 1949, his emphasis on developing systematic theory around the problem of associations (both voluntary and involuntary) and community, and his skepticism toward raw or abstracted empiricism, influenced a line of Columbia sociologists extending from Abel to Merton and eventually to Gouldner.

\section{The MacIver-Lynd Split: Enter Robert K. Merton}

Both Lynd and MacIver led Columbia sociology through the 1930s and into the 1940s. Although the split between humanistic and scientific sociology was still an abiding issue, by the early 1930 s there seemed to exist agreement that the one central substantive issue was understanding the community as a social system. This paralleled the Great Depression that sent many communities into a tailspin of social disorganization, and the subsequent rise of the welfare state. Hence, concrete studies of specific depressed groups were replaced by studies that attempted to explain the workings and functional interrelations of the entire community.

Although Lynd and MacIver were in agreement about the department's general orientation, they disagreed vehemently about the particular scholarly aim that this substantive focus on the community should fulfill. As Lipset (1955, pp. 296-297) explains, 
Lynd tended to emphasize the need for empirical studies which assumed functional interrelationship of all social behavior, but which were oriented toward the strains in the social system. MacIver, on the other hand, stressed the need for more systematic theory concerning the operation of the social system.

Eventually, an irrevocable split between Lynd and MacIver occurred over these differences. Beyond their differences of opinion on substantive grounds, MacIver was also battling Lynd over scholarly reputation and allegiances. The problem was that MacIver's programmatic attempt to establish an agenda for theorizing around his concepts of community and association (MacIver, 1917, 1931, 1937; see Halas, 2001) was becoming overshadowed by the theoretical work of Talcott Parsons (1937) at Harvard. Lynd tended more and more to side with the functionalist strands of Parsons' approach, which was also becoming the accepted theoretical approach in sociology more generally. Although MacIver was also interested in developing systematic theory about the social system, he wanted this work to progress along the analytical lines he had developed in his writings up through Society (MacIver, 1937). This necessarily meant being opposed to the orthodoxy Parsons was developing along similar but competing theoretical lines.

In 1941, in an effort to ameliorate somewhat the split between Lynd and MacIver, two young sociologists were brought in to the sociology department. Paul F. Lazarsfeld was brought in by Lynd to strengthen the empirical orientation of the department, while Robert $\mathrm{K}$. Merton was brought in by MacIver to strengthen the areas of social theory and urban research. ${ }^{3}$ Merton, who had received his Ph.D. in sociology from Harvard where he had studied under Talcott Parsons, arrived from Tulane University, relinquishing a full professorship there for the opportunity to join the Columbia staff as an assistant professor. Among his earliest students was Alvin Gouldner.

Little is known of Gouldner's activities over the two years from his graduation from City College in 1941 to his enrolling in the master's program in sociology at Columbia. ${ }^{4}$ However, thanks to Robert K. Merton's assiduous documentation of his correspondence with the young Gouldner beginning in 1943, we do know that Merton took Gouldner seriously from the start, for his letters were written " . . . in the vein of a fellow scholar addressing serious subjects in a serious manner" (Merton, 1982, p. 917).

Gouldner adopted Merton as his mentor for at least three reasons. First, industrial sociology appealed to Gouldner because of his business background, and Merton, aside from being one of the most eminent sociologists of his day, was also well known for having supervised a number of prominent studies of industrial organization. Second, Gouldner shared broader theoretical interests with Merton, especially in the then "nascent" field of the sociology of knowledge (Merton, 1987, p. 5). The third factor has much to do with an important organizational link that existed between City College of New York and Columbia University. Howard Brown Woolston, who was trained by Giddings at Columbia, dominated the soci-

3. Although Merton's relationship with MacIver remained generally amicable and collegial at Columbia, their working relations remained somewhat at a distance. For example, Merton (1998) reports that while his groundbreaking work on the "self-fulfilling prophecy" was being developed during the 1940 s, MacIver was developing a similar project at about the same time (which he dubbed the "self-fulfilling postulate"). Merton suggests, though, that his convergence with MacIver on the concept of the self-fulfilling prophecy was a simultaneous discovery rather than a case of Merton being directly influenced by MacIver's work.

4. One biographical source (American Men and Women of Science, 12thed., The Social and Behavioral Sciences, volume 1, $A-K$, New York: Jacques Cattell Press, 1973) reports that Gouldner served in the U.S. military during 1942-1943. However, no other published biographies mention such military service, and no one with whom I spoke during the course of my research remembered Gouldner ever having spent time in the military. 
ology curriculum at CCNY and strongly encouraged his better students - those with the proper inclination, desire, and grades - to apply to Columbia University (Gorelick, 1981, pp. 146-159). As was noted earlier, Gouldner was among a handful of predominantly Jewish CCNY students that benefited from this arrangement. Those who were accepted into the master's or doctorate sociology program received special attention from both Robert Lynd and Merton. As Vidich and Lyman (1985, pp. 144-145, note 8) explain,

The roles of Lynd and Merton in acculturating the sons of Jewish immigrants to sociology cannot be underestimated. Lynd, a Protestant ministerial student who had been deeply influenced by Dewey and Veblen, had clashed with Ogburn over the latter's insistence that sociology should become a science for its own sake; Lynd insisted that social scientific knowledge had to serve a social purpose. . . . And they could identify with Merton's ironic style of sociological writing. The ironic is a semiotic of the less powerful, who, though unable to overturn the system that oppresses them, nevertheless only appear to accept their situation while knowingly revealing that they are not taken in by its pretensions.

The authors go on to suggest that this ironic tone is embodied in a number of Merton's theoretical concepts, including "latent functions" and "unintended consequences." It also appears in his most important writings in organizational sociology, which we turn to next.

\section{Merton's Organizational Sociology}

As Crothers (1990) has noted, Robert K. Merton's major contributions to organizational sociology are represented in four essays he published during the 1940s: "Bureaucratic Structure and Personality" (Merton, 1940); "Role of the Intellectual in Public Bureaucracy" (Merton, 1945); "The Machine, the Worker and the Engineer" (Merton, 1947); and "Patterns of Influence: A Study of Interpersonal Influence and Communications Behavior in a Local Community" (Merton, 1949). Additionally, Merton and three of his students edited sociology's first reader in studies of bureaucratic organization (Merton, Gray, Hockey, \& Selvin, 1952). Of these works, Merton's 1940 essay "Bureaucratic Structure and Personality" is probably the most important.

In this essay, Merton summarized Weber's description and characterization of the key features of the modern bureaucracy. It is important to note here that Weber was a major influence on Merton, thanks in large measure to Talcott Parsons. Merton was a student of Parsons' at Harvard in the 1930s, and Parsons himself did more than any other sociologist to introduce Weber's writings to American audiences. For example, in 1930, Parsons translated Weber's Protestant Ethic and the Spirit of Capitalism (originally published in 1904-1905). Later, Parsons (1937) provided an extensive treatment of Weber's work (along with Pareto, Marshall, and Durkheim) in his The Structure of Social Action.

As mentioned earlier, the rise of industrial sociology was characterized by a rather uncritical appropriation of Weber's ideas concerning the structure and characteristics of formal organizations. These works emphasized Weber's notion that the bureaucracy represented the most rational and efficient form of social relations for attaining the specific goals of the organization. By the 1940s, Parsons and others had developed functionalist theory into the most influential paradigm or perspective in sociology. Functionalism, being concerned with identifying the structures and processes of the various parts of society that, through their proper functioning, purport to contribute to the maintenance of society as a whole, tended thereby to place an extreme emphasis on social order and the importance of shared norms and values in maintaining that order.

Although it is true that Merton was influenced by Parsons, and especially his reading of 
Weber, Merton also maintained a somewhat critical perspective on orthodox functionalism and especially the latent critical elements of Weber's thought which Parsons had almost totally neglected. Indeed, as Wrong (1981, p. 40) has suggested, "The Parsonian interpretation of Weber exaggerated the differences from Marx in many areas and sometimes tended to present Weber as a kind of anti-Marx" (see also Cohen, Hazelrigg, \& Pope, 1975). Merton, in fact, brought a critical corrective into orthodox Parsonsian functionalism with the distinctions he made between manifest and latent functions, and especially with his introduction of the concept of "dysfunctions," namely, "those observed consequences which lessen the adaptation or adjustment of the system" (Merton, 1968, p. 105; see also Merton, 1966).

Hence, in "Bureaucratic Structure and Personality," Merton went beyond merely regurgitating Weber's depiction of the characteristics of formal organizations with his discussion of the dysfunctions of bureaucracy. He argued, for example, that since the bureaucracy exists to fulfill some narrowly defined goal or set of goals, predictability of behavior on the part of all actors in the organization is assured through the reliance on such formal, technical criteria as organizational manifests, a highly refined division of labor, an explicit chain of command, and impersonality and objectivity in dealings with and between officeholders. This adherence to rules, originally established as an efficient means for accomplishing the tasks of the bureaucracy, eventually becomes an end in itself, giving rise to the organizational dysfunction that has come to be known as goal displacement, namely, the shifting of organizational goals away from their original intended purpose, "as when an employee does something that interferes with the achievement of the organization's goals in order to protect his or her job" (Coleman \& Cressey, 1996, p. 564). Similarly, discipline, which is valued because it presumably assures conformance with organizational regulations, is transformed into an immediate value in the life-organization of the bureaucrat (Merton, 1940). Hence the bureaucratic personality is one that tends toward ritualism in its obsession with rules and discipline and where the emphasis on procedure and rules qua rules effectively displaces the original substantive aims of the organization altogether.

In essence, through the utilization of the critical potential of Weberian theory, Merton provided a critical perspective in organizational studies without having to invoke Marx, while simultaneously maintaining allegiance to standard (albeit modified) functionalist theory. Merton's reworking of structural-functionalism, and the fact that he was at Columbia, certainly one of the elite centers of American higher education, attracted an impressive group of graduate students eager to carry on his ideas and apply them to organizational studies in particular. As Crothers (1990, p. 194) notes,

But much of the substantial impact of Merton's approach to the study of organizations has been absorbed and also extended by its incorporation in the work of a powerful group of Merton's students - Selznick, Gouldner, Blau and others, including Lipset who laid down the first generation of detailed and intensive case studies of organizations.

Merton (1968, p. 179) understandably took great pride in the accomplishments of his students in developing a more systematic and empirically informed (rather than merely speculative or impressionistic) understanding of bureaucracy. The most important of these studies, Merton suggested, are Selznick (1949), Lipset (1950), Blau (1955), and Gouldner (1954a, 1954b). We turn now to Gouldner's writings in industrial sociology.

\section{GOULDNER's INDUSTRIAL SOCIOLOGY}

Gouldner completed his MA thesis in 1945, then served as resident sociologist on the American Jewish Committee from 1945 to 1947, as an assistant professor at the University 
of Buffalo (1947-1951), as consulting sociologist at Standard Oil Co. in New Jersey (1951 1952), and as an associate professor at Antioch College from 1952 to 1954 (Eldridge, 1998; Mullins, 1973, pp. 54-55).

During these years Gouldner published extensively in the area of organizational sociology, and as Crothers (1990, p. 197) suggested, "One of the first signs of an active and aggressive attempt to establish 'organizational sociology' as a field in its own right came with Alvin Gouldner's brisk comments (1947) [sic] on Moore's review paper on industrial sociology." Crothers referred here to Gouldner's (1948) paper entitled "Discussion," which was part of an American Sociological Review symposium on industrial sociology centering on Wilbert C. Moore's (1948) paper "Industrial Sociology: Status and Prospects." Other contributors besides Gouldner included Robert Dubin, Delbert Miller, and Paul Meadows. (These papers actually appeared in 1948, not 1947 as Crothers reports.) This was Gouldner's third published article, the first two being "Basic Personality Structure and the Subgroup" (Gouldner, 1946) and "Attitudes of 'Progressive' Trade-Union Leaders" (Gouldner, 1947).

Merton's influence on Gouldner was certainly evident in this discussion paper. Gouldner (1948) chastised Moore and others who tended toward an unreconstructed and uncritical appropriation of Weber's work. Because Weber's theory had been held in such high regard among most sociologists, they had allowed the theory to drive their perception of organizations to such an extent that they had failed to "see" what was truly there. Gouldner cited the particular example of "red tape," where a standard appropriation of Weber would explain this phenomenon as arising out of the fact that, because employees of the bureaucracy value the regulations and routines of their duties so much, they tend to lose sight of broader organizational goals, thus leading to mountains of paperwork and delay for customers or clients who are being serviced by the organization. As Gouldner (1948, p. 399) explained,

Sociologists' uniform [i.e., Weberian] explanations of red-tape, together with inadequate attention to the empirical problem, strongly suggests that alternative theoretical systems have not been sufficiently explored to determine what they can offer toward an understanding of this problem.

Gouldner went on to provide explanations of red tape from alternative theoretical perspectives, including gestalt psychology and psychoanalysis. Again, Gouldner's (1948) main point was to suggest that "commitment to one theoretical system, apart from empirical examination of the problem to which it is being applied, is as hazardous as untheoretical research" (p. 400). Here, Gouldner was exhorting sociologists in the "still nascent" field of industrial sociology not to neglect empirical research in favor of merely accepting the received wisdom of master thinkers such as Weber. Merton of course had provided Gouldner with a living, breathing example of such a program of "organized skepticism" (Merton, 1976) with his own critical reconstruction of Parsonian functionalism. And, as we shall see, Gouldner adopted this critical orientation toward theory and the problems associated with the uncritical acceptance of received wisdom throughout the remainder of his career.

While at the University of Buffalo from 1947 and 1951, Gouldner taught courses in sociological theory and fascism, worked on an edited volume on organizational leadership (Gouldner, 1950), and carried out fieldwork in a gypsum plant for his Columbia dissertation. Maurice Stein, at the time an undergraduate student at Buffalo, worked as a research assistant for Gouldner between 1947 and 1949, and actually conducted much of the fieldwork in the gypsum plant and mine (Reinharz, 1995; Stein, 1964). Gouldner completed his dissertation in 1953 while at Antioch College, and was fortunate enough to have two books published from it; the first, Patterns of Industrial Bureaucracy (Gouldner, 1954a), and a later companion 
volume entitled Wildcat Strike (Gouldner, 1954b). We next turn to a brief analysis of Patterns of Industrial Bureaucracy.

\section{Patterns of Industrial Bureaucracy}

As we have seen, Gouldner was strongly influenced by Merton's emphasis on empirical research as a necessary complement to theorizing, by his writings on bureaucratic structure, and by his theory of local versus cosmopolitan influentials (Crothers, 1998). In terms of empirical research specifically, many of the prominent organizational studies that took place at Columbia under Merton's supervision during the 1940s and 1950s "took a case study approach and included broad examination of each organization through extensive observation and use of organizational documents as well as some interviewing" (Crothers, 1990, p. 214). Patterns of Industrial Bureaucracy was no exception.

Gouldner's study of a gypsum plant in upstate New York was concerned with the changes in plant operation before and after a managerial succession. The plant, which Gouldner referred to as the General Gypsum Company (a pseudonym), was located in "Lakeport," a mid-sized city near the Great Lakes.

The great majority of the workers lived in outlying towns on the periphery of Lakeport's metropolitan area. This area supported a population of perhaps 5,000, while the population of the town within which the plant was actually located, "Oscar Center," consisted of only 700 residents. Oscar Center was characterized by a traditional outlook where "familiarity" and "community" were emphasized over "efficiency" with regard to the operation of the plant and to plant-community relations. Over the years the plant had employed generations of families from the local area, hence family welfare and unity were strong values in the plant.

Since so many workers in the plant possessed deep roots in the community stretching back generations, the level of day-to-day familiarity between plant workers was high. As a result, sociability and accommodation between supervisors and subordinates was emphasized and became an integral part of the operation of the gypsum plant. When one worker was asked why everyone seemed to get along in the plant, he responded that the plant is "like one big happy family" (Gouldner, 1954a, p. 39).

Although the values of family and familiarity had always been prominent in the day-today operation of the plant, some changes were underway. The small town ruralism that had characterized the community for so long, and the intimate personalized relationships between workers and managers in the plant, was on the wane. The "old" way of operating the plant, which Gouldner described as the indulgency pattern, was giving way to a new "rational," more "efficient" method of operation. This occurred as a result of a change in upper and middle management.

The new plant manager, "Vincent Peele," set about to rationalize and streamline the operation of the plant. Under the old indulgency pattern, managers were somewhat lenient with workers when it came to absences, tardiness, or helping out with material or family needs (for example, a manager might look the other way while a worker "borrowed" a tool or some other item from the plant). Peele's new management philosophy was to emphasize rational discipline, to enforce the organizational chain of command, to formalize job descriptions, and to require that managers file reports about a broader range of supervisory activities.

In the indulgency pattern, although rules were on the books, they were flexible and open to the discretion of supervisors. Until Peele's arrival, for example, the rules regarding the length of lunch breaks, or punching the clock, were never strictly enforced. Such "leniency" changed with the arrival of the new management team. Gouldner (1954a, p. 59) argued that the arrival of Peele drastically disturbed the pattern of operations that everyone in the plant 
had come to know and expect. In effect, Peele set about to systematically dismantle the old indulgency pattern (p. 66). As Gouldner (1954a, p. 69) summarized: "The violation of the indulgency pattern and the emergence of mature bureaucratic organization were closely interwoven developments; for new orders do not come into existence except by supplanting the old."

Although this was a case study of just one particular industrial plant, Gouldner was attempting to generalize his findings by arguing that managerial succession tends to lead to higher levels of bureaucratization (Gouldner, 1954a, pp. 70-85). In other words, through this research Gouldner was attempting to specify the conditions and factors associated with varying amounts of bureaucracy. Following the theories of Weber and Merton primarily, and based upon his empirical research in the gypsum plant, Gouldner argued for the existence of three "pure" or ideal types of bureaucracy evident in the pattern of rules and programs of any organization.

The first type of bureaucracy was the mock bureaucracy. Gouldner provided the example of the gypsum plant's "no smoking" rule. During their fieldwork, Gouldner and Stein noticed that workers were smoking even with no smoking signs prominently displayed in various parts of the plant. When the researchers asked why this was the case, workers informed them that the rule was a "dead letter" and that the no smoking signs had little to do with company policy; rather, they were put in by the fire insurance writers (Gouldner, 1954a, p. 182). Only on those occasions when fire inspectors were on their way - management would give advanced notice of their arrival — would workers actively refrain from smoking.

The example of the inattention to the no smoking rule provided evidence of the "leeway function" of such rules. As such, the mock bureaucracy was the organizational counterpart of the indulgency pattern that characterized the operation of the gypsum plant before the management succession (Gouldner, 1954a, p. 187).

A second broad type of bureaucracy was the representative bureaucracy. Gouldner found examples of the representative bureaucracy in the safety rules of the plant. In other words, even within the context of the broader indulgency pattern of the mock bureaucracy, there existed a set of operations that were more bureaucratically organized. Rules governing safety were more numerous and complex than rules governing other plant activities. An indication of the higher level of bureaucratization of the safety rules was the complex system of paperwork and reports that were required in this sphere of operation. For example, all cases where workers required first aid, however minor, required an official report to a specially designated "safety engineer" (Gouldner, 1954a, p. 188).

Gouldner referred to this as a representative bureaucracy because there existed a high degree of unanimity among workers that such safety rules were a good thing, and that management could legitimately oversee, regulate, and enforce this aspect of plant operation.

The contrasting of mock to representative bureaucracy led Gouldner to hypothesize that the degree of resistance to bureaucratic forms of administration were determined in some measure by value elements. As Gouldner (1954a) stated, “. . . some workers had little resistance to the safety program, since it was in conformity with their values on personal well-being, cleanliness, and neatness" (pp. 193-194).

Status was also associated with resistance to bureaucratization in that the imposition of such bureaucratic methods could differentially impair the status of certain group members. With regard to safety rules, for example, when a worker was injured, the foreman was often held accountable for the safety of his workers. In this case, it was workers that strove for higher levels of bureaucratization in the form of, say, incorporating safety obligations into the union-management contract. That is to say, if workers perceived management as un- 
willing or unable to fulfill their roles, then it was the workers, not management, that could initiate new bureaucratic forms (Gouldner, 1954a, p. 195).

Did this not seem to contradict the spirit of the representative bureaucracy? Not necessarily, suggested Gouldner. For in the main, management felt that being held to a higher standard of accountability in terms of having to assure a safe working environment led ultimately to a "happier" and hence more productive workforce. In other words, safety was interdependent with productivity (Gouldner, 1954a, p. 197). Hence, otherwise warring values - safety and productivity - were reconciled, thereby preserving the viability of the representative bureaucracy.

A third broad type of bureaucracy was the punishment-centered bureaucracy. The main analytical criterion that distinguished the punishment-centered bureaucracy from the mock and representative forms was the way management responded to deviance on the part of workers (or vice versa). In the punishment-centered bureaucracy, unlike the other two, responses to deviation took the form of punishments. The disciplinary pattern of punishment occurred when management utilized punishment against workers (in the form of reprimands, demotions, or outright termination). In the grievance pattern of punishment, workers subjected management to punishments in the form of strikes, malingering, mass sick calls, sabotage, or other forms of union activity.

Clearly, although some elements of the punishment-centered bureaucracy had previously been evident at the gypsum plant — such as the "no-absenteeism" rule or the "bidding system" incorporated into the labor-management contract - the management succession ushered in a new era of plant operations that elevated the punishment-centered model of bureaucracy to prominence while simultaneously diminishing the mock and representative forms (Gouldner, 1954a, pp. 207-208).

Gouldner ended his study by returning to the original question that sparked this line of inquiry. Weber's work emphasized that the bureaucracy was the most rational and efficient way of ordering social relations for purposes of fulfilling the goal or goals of modern formal organizations. Functionalists too (especially Parsons) picked up this notion and emphasized that the modern bureaucracy is a boundary-maintaining system seeking to accomplish specific goals. But functional for whom? And for what? Gouldner argued that Weber and the later functionalists tended to view these functions as being fulfilled by or pursued for the organization as a whole, without realizing that various parts of the organization may indeed, and often are, pursuing different, sometimes incompatible goals (Gouldner, 1954a, p. 240). Gouldner's empirical work in the gypsum plant, in essence, brought to light the subtleties of conflict and group tensions within the organization and marked a new era of conflict-oriented (rather than normatively oriented or rationalistic) organizational studies.

Gouldner's Wildcat Strike was a companion volume to Patterns of Industrial Bureaucracy published in the same year. The book summarized the events that led to a wildcat strike at General Gypsum Company as a result of the management succession. Gouldner (1954b) developed a theory of group tensions to explain the wildcat strike, and he later extended the scope of the theory (see Gouldner, 1954c) to include a wider range of industrial or organizational conflict beyond strikes per se.

\section{Additional Writings in Industrial Sociology}

Although we have now discussed Gouldner's most important contribution to industrial sociology in some detail, several of his later articles on the subject are also worthy of mention.

After spending two productive but unhappy years at Antioch, Gouldner joined the faculty of the University of Illinois as an associate professor in 1954, the same year that both Patterns 
of Industrial Sociology and Wildcat Strike were published (Merton, 1982, p. 922). Gouldner remained at Illinois from 1954-1959. In 1955, he published an essay in American Political Science Review entitled "Metaphysical Pathos and the Theory of Bureaucracy." Here Gouldner chided sociologists (specifically mentioning Parsons, Warner and Low, and Selznick) for having an overly pessimistic view of bureaucracy. This pessimistic view of formal organization was established both by Weber (his notion of bureaucracy as an "iron cage") and Michels (1915; his notion of the "iron law of oligarchy"). Where Marx argued that workers had nothing to lose by revolting, the Weber/Michels position intimated that workers have nothing to gain (Gouldner, 1955, p. 497). As Gouldner (1955) argued, "For many intellectuals who have erected a theory of group organization on Weberian foundations, the world has been emptied of choice, leaving them disoriented and despairing" (p. 498).

Borrowing Lovejoy's (1948) notion of the "metaphysical pathos of ideas," namely, the tendency for persons to gravitate toward ideas and beliefs that resonate with their own deepseated sentiments or experiences, Gouldner suggested that sociologists such as Parsons and Selznick had embraced the pessimistic view of bureaucracy not because of any systematic, analytical inspection of the idea per se, but because it was congruent with the mood or sentiments of the theorist.

Gouldner believed that much that had been written in the field of organizational sociology up to 1955 tended to blindly follow the masters' voices, namely Michels and especially Weber, and the metaphysical pathos of their ideas (pessimism and fatalism) had insinuated itself into the majority of contemporary writings, even the ones that claimed to liberate workers from the deleterious effects of formal organizations. In essence, Gouldner believed that organizational studies had taken a wrong turn in arguing that bureaucracy is inevitable and pathological rather than potentially humane and liberating. Much of this delusion was caused by sociologists' inattention to the empirical realities of organizations.

As we have seen, Merton emphasized a research program in organizational studies at Columbia University, with the case method being the preferred method for gathering the empirical data that could then be used to more adequately test or generate theory. Gouldner (1954a, 1954b) pointed to his own work in the field, and specifically to his case study of the General Gypsum Company, as an illustration of how organizational studies could be carried out without the excess baggage or metaphysical pathos of pessimism and fatalism that afflicted most other studies.

It is curious to note, however, that the study by Selznick (1949) that Gouldner cited as being needlessly pessimistic arose out of the very same cohort of Columbia case studies that Gouldner lauded as exemplary. Selznick, like Gouldner, employed a case study of the Tennessee Valley Authority, an organization that was widely heralded at the time as representing the highest expression of democratic values. This is because of TVA's emphasis on decentralization of authority and the participation of citizens from the communities affected by its policies and operations. Selznick found, however, that the TVA operated with, and imposed, certain social constraints on service areas that actually thwarted, rather than promoted, democratic aspirations. In effect, Selznick found that, whether voluntary associations of the democratic mass state or citizens' associations of the totalitarian state, the administrative techniques employed by these entities nevertheless tended to converge. As Selznick (1949, p. 9) stated, "The phenomenon of abdication to bureaucratic directives in corporations, in trade unions, in parties, and in cooperatives is so widespread that it indicates a fundamental weakness of democracy."

Here we have an example of a case study arriving at a conclusion about the undemocratic nature of bureaucracy. Selznick interpreted his empirical data in a direction that Gouldner 
found unfavorable. So we must conclude that the method per se - the case method-gave no assurance of escaping the metaphysical pathos of undue pessimism. Following Gouldner, in order to "explain" why Selznick came up with this negative finding, we are left to conclude, then, that Selznick gravitated to a finding that was simply most congenial to his own experiences or sentiments regarding the nature of bureaucracy. But if this is the case, where and what are the benefits of empirical inquiry? If we are destined to be led to certain conclusions that resonate with our own personal proclivities or worldview, regardless of the data, what then? Does not this position take us dangerously close to a radical solipsism?

This was a conundrum that Gouldner grappled with his entire professional career, one that he never adequately resolved. For now we must leave this discussion aside, however, and move on to an examination of Gouldner's (1959a) programmatic statement on organizational analysis that he published at decade's end.

Gouldner (1959a) noted that in its very earliest stages, sociology was somewhat optimistic about industry and formal organization. This was seen especially in Saint-Simon's view of modern organization as a liberating force, "emancipating men from the yoke of tradition and heightening productivity and efficiency" (Gouldner, 1959a, p. 402). Weber, too, acknowledged the gains to modern society of bureaucracy's efficiency, even while bemoaning the ways in which the bureaucracy was destructive of individual personality, especially insofar as it subjected workers to dehumanizing and dulling routine.

What Weber tended to neglect, according to Gouldner, were the nonrational elements upon which the alleged "rational" organization of the bureaucracy rested. That is to say, although subordinates obeyed and deferred to superiors because of their technical knowledge and expertise, they also did so because of tradition, namely, because of the office that he or she held. Weber never fully developed these two sources of bureaucratic authority, namely, authority based on sheer incumbence to office (nonrational) versus authority based upon expertise (rational).

Gouldner's entire career in industrial (or organizational) sociology amounted to a conversation with Weber about the limitations of his formulation of bureaucracy. Heavily influenced by Merton, and with a critical, although largely repressed, Marxism guiding his analysis of texts (hermeneutics), Gouldner attempted to move beyond speculative inquiry and establish the empirical conditions conducive to various modes of authority (Gouldner, 1959a, p. 403). He was also attempting to build a bridge between "pure" and "applied" sociology, and likewise between the still warring factions of "humanistic" and "scientific" sociology (Eldridge, 1998 , p. 888). Part of this program was realized in Pattems of Industrial Bureaucracy and Wildcat Strike, where Gouldner developed the ideal types of the punishment-centered (based largely upon incumbency in office) and representative (based largely upon expertise) bureaucracy, as well as a general theory of group tensions.

To move toward a programmatic statement on the status of organizational studies at the close of the $1950 \mathrm{~s}$, Gouldner had to reconcile two competing models of organizational analysis, namely, the rational model (derived largely from Weber and his followers) and the natural-system model (derived originally from Comte and later reinforced by Michels, Selznick, and contemporary functionalists such as Parsons).

In the rational model, the organization is conceived as having arisen out of the needs of certain groups to accomplish some narrow goal or set of goals, the attainment of which requires the coordinated efforts of a collectivity. In this sense, the organization is viewed as an "instrument," or a rationally conceived means to realize the overtly expressed group goals. It is believed that this particular ordering of social relations represents the most efficient method for attaining the stated goals, and whatever patterns of administration and operation 
emerge out from this are viewed as planned devices for improving the level of efficiency within the organization (Gouldner, 1959a, p. 404). The focus, therefore, is on the legally prescribed structure of the organization.

In the natural-system model, on the other hand, the organization is regarded as a natural whole, or system. Although the goals of the organization are important, they are not paramount in determining the ordering and patterning of relations in the organization. Rather, the goals are viewed as merely one component of the larger, complex organization. The naturalsystem model, being functionalist at heart, views the organization as an organism that is boundary- and equilibrium-maintaining. Since the fulfillment of ends is only one part of the constitution of the organization, the system will continue to strive to maintain itself even if these ends are met or fulfilled. This then leads to the view that, once established, organizations tend to continue on indefinitely, perhaps even fashioning new ends entirely, and perhaps even beyond the willful intervention of flesh-and-blood human beings.

The organicism of the natural-system view of organizations also has embedded within its ontology a physicalist assumption concerning inertia, in terms of viewing organizations as boundary-maintaining systems which tend toward equilibrium, with the various parts of the system functionally interrelated. This equilibrium depends heavily on the conforming behavior of group members (Gouldner, 1959a, p. 423). Gouldner was especially critical of Parsons here, and went about digging out several key implicit assumptions of the Parsonsian natural-system model of organizations. Most importantly, "This model seems to assume that each of a sequence of identical conforming acts will yield either the same or an increasing degree of appreciation or satisfaction and will thus elicit the same or an increasing amount of reward" (Gouldner, 1959a, p. 423). This assumption, although never stated overtly, follows from Parsons' suggestion that, once a system of complementary role-expectations is established within a collectivity of actors (Egos and Alters), the maintenance of such a system over time is assured and relatively unproblematic. As Parsons (1951, p. 205) stated, "No special mechanisms are required for the explanation of the maintenance of complementary interaction-orientation."

Again, the problem with Parsons' formulation was that it assumed relations in the organization are based upon agreement and value consensus, and that social order is maintained and assured relatively unproblematically via this mutually shared normative system. Parsons placed an exaggerated emphasis on harmony and equilibrium in social relations, without seriously considering that social order could be maintained through coercion, through noncompliance, or myriad other possibilities. As an example, Gouldner (1959a, p. 424) cited Merton's (1940) notion that some measure of anomic or nonconforming behavior may be beneficial to group stability. Gouldner had also discovered in his own research that overconformity to role expectations could occur, thereby contributing to instability in the system (as was documented in the case of Peele).

Gouldner suggested that this overweening emphasis on conformity and the norm of reciprocity, where it was assumed that a series of identical conforming acts assures increased conformity, could no longer be defended. As Gouldner (1959a, p. 424) argued,

our analysis suggests that a sequence of identical conforming actions undergoes an inflationary spiral and that later conforming actions are worth less than earlier ones, in terms of the rewards or propensity to reciprocate which they elicit. We cannot assume, therefore, that identical acts of conformity will yield identical increments in group equilibrium.

Gouldner closed his essay by suggesting that the two models of organization will need to be 
reconciled at some point, perhaps leading to a single and synthesized model that could account for the realities of modern organization. And lastly, "Further development of organizational analysis is contingent upon the clarification of the basic models of sociological analysis and the verification of the empirical assumptions on which these models rest" (Gouldner, 1959a, pp. 426-427).

\section{CONCLUSION}

This essay, "Organizational Analysis," effectively closed Gouldner's work in the area of organizational or industrial sociology. He rarely ventured back into the field of organizational sociology proper after 1962, save for a blistering critique of the organizational pathologies of welfare agencies and of social work in particular (Gouldner, 1963). It is curious to note that Gouldner never attempted to develop further or extend his ideas in this area. For example, his general theory of group tensions that appeared so promising in Wildcat Strike and a later paper was never heard from again. Although Gouldner did deal somewhat at length with the "norm of reciprocity" and the idea of a "reciprocity multiplier" within the context of organizations (as we have seen above), after 1959 discussion of these concepts would occur at higher analytical levels, stripped, as it were, of empirical content.

In his later years (after 1962) Gouldner shifted from explicit treatment and discussion of Weber to applications of Marx, to extended forays into the sociology of knowledge, to the problems of contemporary functionalism, and to the creation of a critical program of reflexive sociology. Indeed, during the 1960 s Gouldner settled comfortably into the role of sociological theorist and critic, returning somewhat more explicitly to his Marxian roots. Indeed, by leaving behind the "orthodox" field of industrial sociology, Gouldner experienced a personal transformation from sociology insider (albeit a critical insider) to sociology outsider during the 1960s, and finally to Marxist outlaw throughout the 1970s and up until his death in 1980 .

Although Gouldner's substantive foci changed over these years, the internal sentiments, that is, the infrastructural level of Gouldner's work, always retained the pragmatic orientation of his earlier industrial sociology period, namely, to "solve" problems besetting modern industrial society (and its bureaucratic organization) through empirical research and the creation and testing of appropriate theories. Gouldner also was successful in pointing out that organizational theory - both the rational and natural systems models - had for too long problematized only the boundary between the organization and its external environment without realizing that the boundaries within various segments of the organization were equally problematic and rife with potential or real conflict (Cooper, 1986). This is a reality that is often overlooked in today's organizations which are experiencing acute levels of structural differentiation, segmentation, and individualization. Importantly, Gouldner's insights broadly reflect the ironic vision of social organization that he learned from Merton.

Serious theorizing that takes into account the hard realities of bureaucracy, rather than the wishful or fanciful thinking of theorists, managers, or consultants, was Gouldner's way of solving the persistent problems besetting modern society and its organizations. In this sense, Gouldner (1974b) subscribed to the "generic ideology" of most intellectuals, namely, that ideas are potent, and that worlds can be changed, hopefully for the better, with the appropriate theory. But unlike many applied theorists working in the field of industrial or organizational sociology, Gouldner also understood the danger of blind or unexamined allegiances to certain ideas (such as those of Weber or Parsons or Marx) or organizations (such as the welfare state) that hold sway during any particular disciplinary epoch.

Gouldner's warnings have been prescient particularly in the field of organizational stud- 
ies, as organizational scholars, managers, and organizational consultants are still prone to adopt certain faddish trends (e.g., TQM, empowerment, self-esteem) only to drop them when they have seemingly run their course (Chriss, 1999b). Gouldner's industrial sociology attempted to strike a precarious balance between these two countervailing forces by, on the one had, developing a solid body of theory grounded in empirical research, so as to avoid the problems of faddishness and relativism, while, on the other hand, ensuring that the theory is sufficiently self-reflexive and self-critical so as to avoid the perils of blind partisanship or succumbing to the dictates or mandates of perceived authority figures. Sociologists, whether involved in the "pure" area of organizational studies or the "applied" area of organizational consulting, would do well to heed, learn from, and pass on Gouldner's cautionary tale.

\section{REFERENCES}

Abbott, A. (1999). Department and discipline: Chicago sociology at one hundred. Chicago: Chicago University Press.

Alt, J. (1981). Alvin W. Gouldner (1920-1980). Telos, 47, 198-203.

Barnard, C. I. (1938). The functions of the executive. Cambridge: Harvard University Press.

Blau, P. M. (1955). The dynamics of bureaucracy. Chicago: University of Chicago Press.

Chriss, J. J. (1999a). Alvin W. Gouldner: Sociologist and outlaw Marxist. London: Ashgate.

Chriss, J. J. (1999b). Management and supervisory practice in the organization: The relevance of Goffman and Habermas. Sociological Imagination, 36, 217-237.

Chriss, J. J. (2000). Alvin W. Gouldner and the tragic vision in sociology. Social Thought and Research, 23, 199226.

Cohen, J, Hazelrigg, L. E., \& Pope, W. (1975). De-Parsonizing Weber: A critique of Parsons' interpretation of Weber's sociology. American Sociological Review, 40, 229-241.

Coleman, J. W., \& Cressey, D. R. (1996). Social problems (6th ed.). New York: Harper Collins.

Colvard, R. (1990). Gouldner is always worth reading. American Sociologist, 20, 381-384.

Cooper, R. (1986). Organization/disorganization. Social Science Information, 25 (2), 299-335.

Coser, L. A. (1982). Remembering Gouldner: Battler, conquistador, and free intelligence. Theory and Society, 11, 885-888.

Crothers, C. (1990). The dysfunctions of bureaucracies: Merton's work in organizational sociology. In J. Clark, C. Modgil, \& S. Modgil (Eds.), Robert K. Merton: Consensus and controversy (pp. 193-226).London: Falmer Press.

Crothers, C. (1998). Patterns of manifest and latent influence: A double case study of influences on and from Robert K. Merton. In C. Mongardini \& S. Tabboni (Eds.), Robert K. Merton and contemporary sociology (pp. 197210). New Brunswick: Transaction Publishers.

Eldridge, J. (1998). Gouldner, Alvin W. (1920-1980). In M. Poole \& M. Warner (Eds.), The IEBM handbook of human resource management (pp. 887-891). London: ITP Business Press.

Etzkowitz, H. (1991). The contradictions of radical sociology: Ideological purity and dissensus at Washington University. In M. Oppenheimer, M. J. Murray, \& R. F. Levine (Eds.), Radical sociologists and the movement (pp. 74-95). Philadelphia: Temple University Press.

Fischer, F., \& Sirianni, C. (Eds.). (1984). Critical studies in organization and bureaucracy. Philadelphia: Temple University Press.

Gordon, M. M. (1954). Social structure and goals in group relations. In M. Berger, T. Abel, \& and C. H. Page (Eds.), Freedom and control in modern society (pp. 141-157). Toronto: D. Van Nostrand Company, Inc.

Gorelick, S. (1981). City College and the Jewish poor: Education in New York, 1880-1924. New Brunswick NJ: Rutgers University Press.

Gouldner, A. W. (1946). Basic personality structure and the subgroup. Journal of Abnormal and Social Psychology, $41,356-358$.

Gouldner, A. W. (1947). Attitudes of "progressive" trade-union leaders. American Journal of Sociology, 52, 389392 .

Gouldner, A. W. (1948). Discussion. American Sociological Review, 13, 396-400.

Gouldner, A. W. (Ed.). (1950). Studies in leadership. New York: Harper and Bros.

Gouldner, A. W. (1954a). Patterns of industrial bureaucracy. Glencoe: Free Press.

Gouldner, A. W. (1954b). Wildcat strike. Yellow Springs OH: Antioch Press.

Gouldner, A. W. (1954c). The problem of loyalty in groups under tension. Social Problems, 2, 82-88.

Gouldner, A. W. (1955). Metaphysical pathos and the theory of bureaucracy. American Political Science Review, $49,496-507$

Gouldner, A. W. (1956). Some observations on systematic theory. In H. Zetterberg (Ed.), Sociology in the United States of America (pp. 34-42). Paris: UNESCO. 
Gouldner, A. W. (1957). Cosmopolitans and locals: Toward an analysis of latent social roles-I. Administrative Science Quarterly, 2, 281-306.

Gouldner, A. W. (1958). Cosmopolitans and locals: Toward an analysis of latent social roles-II. Administrative Science Quarterly, 2, 444-480.

Gouldner, A. W. (1959a). Organizational analysis. In R. K. Merton, L. Broom, \& L. S. Cottrell, Jr. (Eds.), Sociology today: Problems and prospects (Vol.2, pp. 400-428). New York: Harper Torchbook.

Gouldner, A. W. (1959b). Reciprocity and autonomy in functional theory. In L. Gross (Ed.), Symposium on sociological theory (pp. 241-270). Evanston IL: Row and Peterson.

Gouldner, A. W. (1960). The norm of reciprocity. American Sociological Review, 25, 161-178.

Gouldner, A. W. (1962). Anti-minotaur: The myth of a value-free sociology. Social Problems, 9, 199-213.

Gouldner, A. W. (1963). The secrets of organizations. In The Social Welfare Forum, 1963 (pp. 161-177). New York: Columbia University Press.

Gouldner, A. W. (1965). Enter Plato: Classical Greece and the origins of social theory. New York: Basic Books.

Gouldner, A. W. (1968). The sociologist as partisan: Sociology and the welfare state. American Sociologist, 3, 103116.

Gouldner, A. W. (1969). Personal reality, social theory, and the tragic dimension in science. In G. Boalt, The sociology of research (pp. xvii-xxxviii). Carbondale: Southern Illinois University Press.

Gouldner, A. W. (1970a). The coming crisis of western sociology. New York: Avon.

Gouldner, A. W. (1970b). Toward the rational reconstruction of sociology. Social Policy, 1, 18-25.

Gouldner, A. W. (1973a). For sociology: Renewal and critique in sociology today. New York: Basic Books.

Gouldner, A. W. (1973b). For sociology: "Varieties of political expression" revisited. American Journal of Sociology, $78,1063-1093$.

Gouldner, A. W. (1974a). Toward the new objectivity: An introduction to Theory and Society. Theory and Society, $1, \mathrm{i}-\mathrm{V}$.

Gouldner, A. W. (1974b). Marxism and social theory. Theory and Society, 1, 17-35.

Gouldner, A. W. (1974c). The metaphoricality of Marxism and the context-freeing grammar of socialism. Theory and Society, 1, 387-414.

Gouldner, A. W. (1975). Sociology and the everyday life. In L.A. Coser (Ed.), The idea of social structure (pp. 417432). New York: Harcourt Brace Jovanovich.

Gouldner, A. W. (1975-1976). Prologue to a theory of revolutionary intellectuals. Telos, 26, 3-36.

Gouldner, A. W. (1976a). The dialectic of ideology and technology. New York: Oxford University Press.

Gouldner, A. W. (1976b). The dark side of the dialectic: Toward a new objectivity. Sociological Inquiry, 46, 3-15.

Gouldner, A. W. (1977-1978). Stalinism: A study of internal colonialism. Telos, 34, 5-48.

Gouldner, A. W. (1978a). The new class project, I. Theory and Society, 6, 153-203.

Gouldner, A. W. (1978b). The new class project, II. Theory and Society, 6, 343-389.

Gouldner, A. W. (1978c). News and social science as ideology. Quarterly Journal of Ideology, 2, 4-17.

Gouldner, A. W. (1979). The future of intellectuals and the rise of the new class. New York: Seabury Press.

Gouldner, A. W. (1980). The two Marxisms. New York: Oxford University Press.

Gouldner, A. W. (1982). Marx's last battle: Bakunin and the First International. Theory and Society, 11, 853-884.

Gouldner, A. W. (1983). Artisans and intellectuals in the German Revolution of 1848 . Theory and Society, 12, 521532 .

Gouldner, A. W. (1985). Against fragmentation: The origins of Marxism and the sociology of intellectuals. New York: Oxford University Press.

Gouldner, A. W., \& Peterson, R. A. (1962). Notes on technology and the moral order. Indianapolis IN: BobbsMerrill.

Gurock, J. S. (1979). When Harlem was Jewish, 1870-1930. New York: Columbia University Press.

Halas, E. (2001). How Robert M. MacIver was forgotten: Columbia and American sociology in a new light, 19291950. Journal of the History of the Behavioral Sciences, 37, 27-43.

Hamblin, R. L. (1989). Sociology and a developing administrative tradition at Washington University: 1957-1971. American Sociologist, 20, 324-329.

Horowitz, I. L. (1990). Daydreams and nightmares: Reflections on a Harlem childhood. Jackson: University Press of Mississippi.

Lazarsfeld, P. F., \& Merton, R. K. (1954). Friendship as social process: A substantive and methodological analysis. In M. Berger, T. Abel, \& and C. H. Page (Eds.), Freedom and control in modern society (pp. 18-66). Toronto: D. Van Norstrad Company, Inc.

Lipset, S. M. (1950). Agrarian socialism: The cooperative commonwealth federation in Saskatchewan. Berkeley: University of California Press.

Lipset, S. M. (1954). The political process in trade unions: A theoretical statement. In M. Berger, T. Abel, \& and C. H. Page (Eds.), Freedom and control in modern society (pp. 82-124). Toronto: D. Van Nostrand Company, Inc.

Lipset, S. M. (1955). The department of sociology. In R. G. Hoxie (Ed.), A history of the faculty of political science, Columbia University (pp. 284-303). New York: Columbia University Press.

Lovejoy, A. O. (1948). The great chain of being. Cambridge MA: Harvard University Press.

Lynd, R. S., \& Lynd, H. M. (1929). Middletown: A study in American culture. New York: Harcourt Brace. 
MacIver, R. M. (1917). Community: A sociological study. London: Macmillan.

MacIver, R. M. (1919). Labor in the changing world. New York: Dutton.

MacIver, R. M. (1931). Society: Its structure and changes. New York: Long and Smith.

MacIver, R. M. (1937). Society. New York: Farrar and Rinehart.

Mayo, E. (1933). The human problems of an industrial civilization. Cambridge MA: Harvard University Press.

Merton, R. K. (1940). Bureaucratic structure and personality. Social Forces, 18, 560-568.

Merton, R. K. (1945). Role of the intellectual in public bureaucracy. Social Forces, 23, 405-415.

Merton, R. K. (1947). The machine, the worker and the engineer. Science, 105, 79-84.

Merton, R. K. (1949). Patterns of influence: A study of interpersonal influence and communications behavior in a local community. In P. Lazarsfeld \& F. Stanton (Eds.), Communications in research, 1948-49 (pp. 180-219). New York: Harper and Brothers.

Merton, R. K. (1966). Social problems and sociological theory. In R. K. Merton \& R. A. Nisbet (Eds.), Contemporary social problems (2nd ed., pp. 775-823). New York: Harcourt, Brace and World.

Merton, R. K. (1968). Social theory and social structure. New York: Free Press.

Merton, R. K. (1976). Sociological ambivalence and other essays. New York: Free Press.

Merton, R. K. (1982). Alvin W. Gouldner: Genesis and growth of a friendship. Theory and Society, 11, 915-938.

Merton, R. K. (1987). Three fragments from a sociologist's notebooks: Establishing the phenomenon, specified ignorance, and strategic research materials. Annual Review of Sociology, 13, 1-28.

Merton, R. K. (1998). Unanticipated consequences and kindred sociological ideas: A personal gloss. In C. Mongardini \& S. Tabboni (Eds.), Robert K. Merton and contemporary sociology (pp. 295-318). New Brunswick NJ: Transaction Publishers.

Merton, R. K., Gray, A. P., Hockey, B., \& Selvin, H. C. (Eds.). (1952). Reader in bureaucracy. Glencoe IL: Free Press.

Michels, R. (1915). First lectures in political science (A. de Grazia, Trans.). Minneapolis MN: University of Minnesota Press.

Miller, D. C., \& Form, W. H. (1951). Industrial sociology. New York: Harper and Brothers.

Miller, D. C., \& Form, W. H. (1964). Industrial sociology (2nd ed.). New York: Harper and Row.

Mills, C. W. (1959). The sociological imagination. New York: Oxford University Press.

Moore, W. C. (1948). Industrial sociology: Status and prospects. American Sociological Review, 13, 382-391.

Mullins, N. C. (1973). Theories and theory groups in contemporary American sociology. New York: Harper and Row.

Nord, W. R. (1992). Alvin W. Gouldner as intellectual hero. Journal of Management Inquiry, 1, 350-355.

Page, C. H. (1982). Fifty years in the sociological enterprise: A lucky journey. Amherst: University of Massachusetts Press.

Parsons, T. (1937). The structure of social action. Glencoe IL: Free Press.

Parsons, T. (1951). The social system. Glencoe IL: Free Press.

Reinharz, S. (1995). The Chicago School of sociology and the founding of the graduate program in sociology at Brandeis University: A case study in cultural diffusion. In G. A. Fine (Ed.), A second Chicago School? (pp. 273-321). Chicago: University of Chicago Press.

Selznick, P. (1949). TVA and the grass roots. Berkeley: University of California Press.

Stark, E. (1991). Talking sociology: A sixties fragment. In M. Oppenheimer, M. J. Murray, \& R. F. Levine (Eds.), Radical sociologists and the movement (pp. 54-73). Philadelphia: Temple University Press.

Stein, M. R. (1964). The eclipse of community: Some glances at the education of a sociologist. In A. J. Vidich, J. Bensman, \& M. R. Stein (Eds.), Reflections on community studies (pp. 207-232). New York: Wiley and Sons.

Traub, J. (1994). City on a hill: Testing the American dream at City College. Reading MA: Addison-Wesley.

Turner, S. P., \& Turner, J. H. (1990). The impossible science: An institutional analysis of American sociology. Newbury Park CA: Sage.

Vidich, A. J., \& Lyman, S. M. (1985). American sociology: Worldly rejections of religion and their directions. New Haven CT: Yale University Press.

Waters, M. (1996). Daniel Bell. London: Routledge.

Weber, M. (1930). The Protestant ethic and the spirit of capitalism (T. Parsons, Trans.). London: Allen and Unwin. (Original work published 1904-1905)

Wrong, D. H. (1981). Max Weber and contemporary sociology. In B. Rhea (Ed.), The future of the sociological classics (pp. 39-59). London: Allen and Unwin.

Zey-Ferrell, M., \& Aiken, M. (Eds.). (1981). Complex organizations: Critical perspectives. Glenview IL: Scott, Foresman and Company.

Znaniecki, F. (1954). Social groups in the modern world. In M. Berger, T. Abel, \& C. H. Page (Eds.), Freedom and control in modern society (pp. 125-140). Toronto: D. Van Nostrand Company, Inc. 